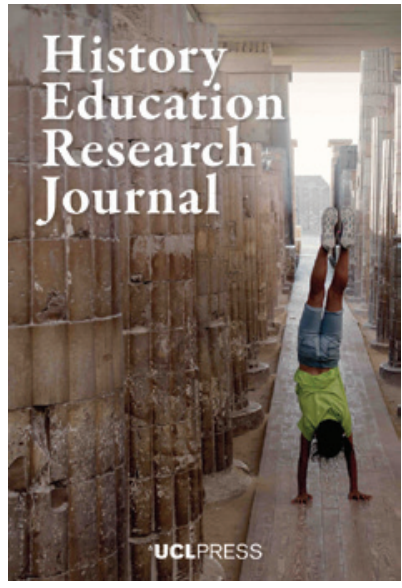

${ }^{\Perp}$ UCLPRESS

HISTORY EDUCATION RESEARCH JOURNAL

ISSN 2631-9713 (Online)

Journal homepage:

https://www.uclpress.co.uk/pages/history-educationresearch-journal

\title{
What aspects of historical understanding feature in the analysis of moving-image sources in the history classroom?
}

\section{Alexander Cutajar (iD}

\section{How to cite this article}

Cutajar, A. (2020) 'What aspects of historical understanding feature in the analysis of moving-image sources in the history classroom?' History Education Research Journal, 17 (2), 195-213. Online. https://doi.org/10.14324/HERJ.17.2.05

Submission date: 16 July 2019

Acceptance date: 10 May 2020

Publication date: 20 October 2020

\section{Peer review}

This article has been peer reviewed through the journal's standard double-blind peer review, where both the reviewers and authors are anonymized during review.

\section{Copyright}

(C) 2020 Cutajar. This is an open-access article distributed under the terms of the Creative Commons Attribution Licence (CC BY) 4.0 https://creativecommons.org/licenses/by/4.0/, which permits unrestricted use, distribution and reproduction in any medium, provided the original author and source are credited.

\section{Open access}

The History Education Research Journal is a peer-reviewed open-access journal. 


\title{
What aspects of historical understanding feature in the analysis of moving-image sources in the history classroom?
}

\author{
Alexander Cutajar* - University of Malta, Malta
}

\begin{abstract}
This paper reflects on aspects of historical understanding developed in a classroom in which moving-image sources are analysed. Considered as nonfictional representations of the past, moving-image sources comprised broadcast images of historical events on newsreels, news broadcasts and documentaries. The study, carried out in a Maltese state secondary school, involved students (aged 15/16 years) analysing moving images as historical sources in their history lessons. Various aspects of understanding were identified: making connections with media content; using knowledge of one topic to shape another; discussing forms of historical knowledge in relation to each other; connecting with the wider historical picture; and constructing meaning using various language strategies. It is argued that these aspects offer a characterization of historical understanding when analysing broadcast footage of historical events in a constructivist classroom. It is suggested that underlying these aspects was students' prior historical knowledge. I highlight the importance of maximizing on opportunities provided by movingimage sources to support understanding, particularly the co-construction of knowledge.
\end{abstract}

Keywords: historical understanding; moving-image sources; history classroom; prior knowledge; secondary education; Malta

\section{Introduction}

Understanding forms an important aspect of the learning process. A central aspect of understanding is the ability to make connections (Newton, 2012). White and Gunstone (1992) make the point that understanding develops when new elements are acquired and linked with the existing pattern of associations between elements of knowledge. As such, understanding is a personal endeavour, the outcome of one's own meaning making (Husbands, 1996; Newton, 2012). In history education, the development of historical understanding is a primary goal of the curriculum. According to Seixas (1996: 767), the central task of historical understanding is to organize 'our collective experience of the past -i.e., the traces and presentations of the past that we encounter in the present - in such a way that they provide a meaningful context for our present experiences'.

In an educational context influenced by technology and visual information (Donnelly, 2013), using moving-image sources in history lessons has become common practice (Haydn et al., 2015). Moving-image sources are here taken to mean broadcast images of key twentieth- and twenty-first-century historical events shown on newsreels (for example, British Pathé), broadcast on television (for example, news programmes) 
or featured in historical documentaries (non-fictional). Unlike feature films, seen as 'cinematic portrayals of the past' (Woelders, 2007: 145), moving-image sources in this study comprised real-time footage and did not feature dramatized representations of the past. Using broadcast images in the history classroom accords with how students interact with a range of media images in everyday life. However, while students bring to the classroom their own knowledge, skills and experiences of evaluating visual content (Card, 2011), a lack of critical analysis skills may compromise questioning the accuracy and trustworthiness of such images (Marcus and Stoddard, 2009). Although feature films have been used in history and social studies classrooms to develop aspects of disciplinary thinking, such as empathy (Marcus, 2005; Marcus et al., 2006; Marcus and Stoddard, 2007; Metzger and Suh, 2008), historical interpretation and the construction of history (Banham and Hall, 2003; Lang, 2002; Morgan, 2010; Seixas, 1994), and bias (Mitchell Cates, 1990), Donnelly (2013) reports that teachers are less confident investigating films as historical artefacts than with printed sources. Where non-fictional historically themed media are concerned, hardly anything is known about how historical understanding develops when students are engaged in the task of moving-image analysis. As Van Drie and Van Boxtel (2010: 38) argue, 'what really matters in terms of developing understanding in history is what students actually do with the information they find: how they use it to create an image of the past'.

This paper reflects on findings from a study investigating the use of movingimage sources in a Maltese secondary history classroom. It highlights aspects of historical understanding developed when moving images are analysed. It is argued that students are able to make different types of connections that contribute to their historical understanding, and to adopt various strategies to do this. It will be suggested that underlying such connections was the activation and deployment of prior knowledge. I argue for the importance of maximizing on opportunities provided by moving-image sources to support students' understanding, particularly the coconstruction of knowledge in whole-class discussions.

\section{Historical understanding}

Significant claims have been made about the importance of historical understanding to history education. Haydn et al. (2015) assert that the greater the sophistication of students' understanding of procedural concepts in relation to historical content, the greater is the depth of their historical understanding. Pickles (2010a) makes the point that arriving at conclusions from historical sources involves drawing on a complex range of understandings related to the discipline of history. Such claims are based on the premise that historical understanding involves the simultaneous development of substantive knowledge and procedural, or second-order, knowledge (Ashby et al., 2005; Haydn et al., 2015; Lee, 2005). Lee's (2005) model of historical understanding includes, in part: substantive understanding, which involves, among other things, studying people's ways of life, beliefs and values; and procedural understanding, which deals with second-order concepts such as evidence and cause and effect. Crucially, Lee (ibid.) proposes that for historical understanding to develop, a topic must be set in a wider historical framework. Having a 'big picture' of the past is necessary for developing historical consciousness (Shemilt, 2009) and for interpreting historical events (Van Boxtel and Van Drie, 2012).

Lee and Ashby's (2000: 200) argument that 'understanding is never all-ornothing' implies that students can reach different levels of sophistication in historical understandings at different stages in their history education. At the higher levels of 
understanding, sophisticated historical thinkers would be those making significant progress in understanding both the substance of the past and the procedural ideas and concepts required to make sense of it (Lévesque, 2008). But, based on CHATA (Concepts of History Teaching and Approaches, 7 to 14) findings, while a student may have an advanced understanding of evidence in class, her/his causal and empathic ideas may not be fully grasped, and understanding of concepts of time and change may be below the class average (Ashby et al., 2005). This points towards understanding being very individual.

In response to criticism that the notion of progression has focused less on the acquisition of substantive concepts (Counsell, 2011; Fordham, 2015), in England, attention shifted towards understanding progression within the substantive domain of history (Fordham, 2016; Hammond, 2016; Palek, 2015). Students' understanding of substantive ideas influences the effectives of the use of knowledge and leads to more analysis of the meaning of sources (Pickles, 2010a, 2010b). The use of relevant substantive concepts enabled students to apply an understanding of the secondorder concepts of historical significance, change and cause (Van Boxtel and Van Drie, 2013). Furthermore, Hammond (2014) reports that in writing tasks, students' strongest arguments came from those drawing on topic, period and general domains of knowledge, whereas students with weaker analysis seemed to discuss mostly topic knowledge.

It is to be noted that the terms 'historical understanding' and 'historical thinking' are used interchangeably in research (for example, Lévesque, 2008; Seixas, 1996). Broadening the area to include 'historical reasoning', Van Boxtel and Van Drie (2013) link historical reasoning with knowledge and understanding; for them, historical reasoning is a competency to develop, helping students to make productive use of their historical knowledge in order to be able to develop deeper understanding. Historical thinking and reasoning form part of the process by which understanding is achieved. As VanSledright (2014) remarks, historical understanding is the outcome of a complex process of thinking historically.

Based on the above, important considerations for researching historical understanding when using moving-image sources can be drawn. First, understanding is seen to develop incrementally, for instance, by building on students' prior knowledge and experiences (Levstik and Barton, 2001). Second, given that historical thinking and reasoning form part of the process by which understanding is achieved (Van Boxtel and Van Drie, 2013), it can be argued that the sources with which students are working, such as moving images, influence their mental processes and, therefore, understanding can be taken to refer to the link between students' thinking and reasoning while working with sources and their ability to apply that reasoning to the learning context. Third, historical understanding entails developing a wider historical view of events (Lee, 2005). Fourth, if understanding is about building personal understandings, students adopt their own strategies of demonstrating understanding.

Informed by these reflections, the research question addressed was: What aspects of historical understanding feature in the analysis of moving-image sources?

\section{Method}

With topics about twentieth- and twenty-first-century history (for example, 'Malta at war', 'the Cold War'), the Year 11 syllabus (DLAP, 2012) was chosen because of varied opportunities to analyse moving-image extracts alongside a range of historical sources. The research site consisted of a history option classroom in a Maltese state secondary 
school, involving two male-only, mixed-ability cohorts in Year 11 (ages 15/16), which in Malta means the final year of secondary schooling. The study involved 14 student participants (cohort $1=4$ students; cohort $2=10$ students). A pilot study, composed of 8 students, preceded the main study. At the time of research, a co-educational system was gradually being introduced in Maltese secondary classes, and Year 11 classes were still single sex. History is a compulsory subject for students up to Year 11, but students may also choose to study history as an option subject. Students choose two option subjects to study in their secondary school years (Years 9-11). The history option comprises a three-year programme covering the years from 1530 (the arrival of the Knights of St John in Malta) to 2004 (Malta's entry into the European Union). With two weekly double lessons (80 minutes each), there is scope for in-depth coverage of themes. Being an option subject, student numbers vary from one year to another.

Focusing on non-fictional broadcast media, moving-image sources comprised newsreels, news broadcasts and documentaries, and were chosen from various websites (for example, British Pathé YouTube channel) according to their relevance to the syllabus topics and appropriateness to students' abilities. Moving-image material was not presented in isolated contexts, but was used in conjunction with other types of sources.

Data sources included transcribed teacher-student dialogues in whole-class conversations and students' writings, gathered from each cohort over 12 lessons. Following dialogic pedagogy (Alexander, 2008), historical knowledge was coconstructed in whole-class discussions (Van Boxtel and Van Drie, 2013). Considering moving images as historical artefacts that need investigation (Donnelly, 2016), teacher questions posed during the analysis of moving images targeted both content knowledge (for example, What do we see happening in this moving image? What are people doing? How are the media reporting the news of ' $x$ '?) and procedural knowledge (for example, What does this moving image tell us about ' $x$ '? What is there in the moving image to show you this? How is this moving image connected to ' $x$ '? What was the purpose of the newsreel showing ' $x$ '? How useful are these images in providing a reliable picture of ' $x$ '?). Seen as a way of consolidating and communicating understanding, writing tasks followed whole-class discussions; they were carried out either in class or at home. These questions required students to show what they understood about the moving image (for example, What are the sequences of moving images about?), demonstrate the extent to which they were able to recall particular details seen in the moving image (for example, Is there any phrase in the moving image that captured your attention?), look out for and discuss evidence (for example, What is there in the documentary to show you that Gorbachev was different from other Soviet leaders?), reflect on what they watched (for example, What do you think was the message that John F. Kennedy wanted to deliver?), and think in terms of evidence lying beyond the moving image (for example, What other sources would you consult to find out more about what happened in Poland?). Moving images were paused whenever I wanted to ask a question, or when students needed to comment or ask about something.

Each cohort was taught by me for a school year. As the teacher-researcher responsible for collecting all data, I was aware of, and acted on, issues such as the familiarity problem (Delamont, 1990), the teaching-research gap (Vanderlinde and Van Braak, 2010), and generalizability (Wilson et al., 2001).

Data were first analysed for substantive and procedural knowledge, and findings presented and discussed in this paper ran through these areas. Following Chi (1997), it was useful to segment transcribed data into portions of text, with each portion 
showing a noteworthy discussion about an idea discussed between the students and me. Transcripts were coded based on emergent themes and on the literature. To ensure reliability, samples of data from different lessons of both cohorts were given to a moderator to be coded. Analytically, I adopted mainly a qualitative approach. To handle the data, QSR NVivo 11 was chosen, which also allowed for some quantitative data analysis.

\section{Findings}

The following aspects of historical understanding emerged from the data:

- making connections with the visual and auditory content

- using knowledge of one topic to shape another

- discussing forms of historical knowledge in relation to each other

- connecting with the wider historical picture

- constructing meaning using various language strategies.

These will be presented, analysed and discussed in this order. Excerpts of student data are intended to illustrate the general pattern that emerged.

\section{Making connections with the visual and auditory content}

Students made various connections when watching and analysing moving images. These consisted of verbal utterances regarding particular visual or auditory content that connected with information they already knew. Different kinds of associations were made, expressed on 86 occasions (see Table 1).

\section{Table 1: Making associations}

\begin{tabular}{lll}
\hline $\begin{array}{l}\text { Associations made } \\
\text { by students }\end{array}$ & $\begin{array}{l}\text { Number of students who } \\
\text { established an association } \\
\text { at least once }\end{array}$ & $\begin{array}{l}\text { Total number of coded references in } \\
\text { relation to each type of association } \\
\text { N=86 }\end{array}$ \\
\hline Historical event & 11 & 26 \\
Historical figures & 6 & 12 \\
Country/location & 6 & 18 \\
Analogy & 7 & 11 \\
Present-day politicians & 3 & 4 \\
Current events & 4 & 5 \\
Objects & 2 & 2 \\
Personal interests & 5 & 8 \\
\hline
\end{tabular}

The most frequent association concerned a historical event. A common association with the same historical event was established by two students from different cohorts in the lesson 'The Berlin airlift'. Kyle and Noel likened the planes airlifting goods to West Berliners to the convoys delivering goods to the Maltese during the Second World War: 'It was like our [Maltese] convoy but using the plane instead' (Kyle), and 'So these aeroplanes were very much like the convoys' (Noel). Students also made a connection with historical figures (for example, Hitler) and a country (for example, Libya), or a particular location in a country (for example, the Berlin Wall). Students established an association in the form of an analogy on 11 occasions. Associations were also made with present-day politicians (for example, Joseph Muscat, the Maltese 
prime minister), current events (for example, CHOGM - the Commonwealth Heads of Government Meeting), objects (for example, Molotov cocktail) and personal interests (for example, book).

This finding suggests that students may link information they watch or listen to with their prior knowledge, without teacher probing. Thus, visual and auditory fragments in moving-image extracts seemed to trigger mental associations that went beyond the immediate scene, and that students verbalized in class discussions. Various explanations could account for this: knowledge students had gained over the years in school history, and perhaps in other subjects; being well informed about current affairs; or just sheer coincidence. The examples above support Konnikova's (2013) observation that it is the tendency of a reasoning mind to pick any relevant information and retrieve cues that may be seemingly connected, even though they may not actually matter. Based on the above, making connections could be interpreted as a sign of an engaged mind (Cutajar, 2018).

\section{Using knowledge of one topic to shape another}

Another aspect of understanding concerned students' use of knowledge gained across topics, revealed mostly in the use of substantive concepts. Concepts pertained to three categories: political (for example, revolution); economic (for example, industrialization); and social/cultural (for example, convoy). As seen in Table 2, of the 95 concepts mentioned at least once during all the lessons, some (for example, war, communism, democracy, superpowers) were encountered across lessons more in whole-class discussions than in writing.

\section{Table 2: Number of concepts in each lesson and their frequency in units of data}

\begin{tabular}{llll}
\hline Lesson & $\begin{array}{l}\text { No. of concepts } \\
\text { mentioned at } \\
\text { least once } \\
\text { N=95 }\end{array}$ & $\begin{array}{l}\text { No. of units of } \\
\text { data for class } \\
\text { dialogues } \\
\mathrm{N}=185\end{array}$ & $\begin{array}{l}\text { No. of units } \\
\text { of data for } \\
\text { writing tasks } \\
\mathrm{N}=75\end{array}$ \\
\hline Malta's use as a naval base & 13 & 25 & 8 \\
Malta's condition during the war & 7 & 19 & 2 \\
The Iron Curtain & 11 & 17 & 9 \\
Berlin airlift & 6 & 12 & 3 \\
Hungarian revolt & 14 & 21 & 7 \\
Building of Berlin Wall & 8 & 10 & 7 \\
Cuban missile crisis & 3 & 6 & 10 \\
Solidarność & 10 & 23 & 8 \\
Dismantling of the USSR & 5 & 7 & 8 \\
Fall of the Berlin Wall & 7 & 8 & 9 \\
Motives for the EU & 9 & 17 & - \\
Terrorism & 2 & 20 & 4 \\
\hline
\end{tabular}

The following extract, analysing a moving image about Poland in the 1980s, taken from the lesson 'Solidarność, illustrates how students transferred knowledge gained from previous lessons about episodes from the Cold War to make sense of the Polish context. In answer to my question about Moscow's concern with Solidarność, as mentioned in the moving image, Noel referred to the 'right to strike', and Daniel likened the trade 
union to a 'political party'. Clive drew on knowledge gained from the lesson about the Hungarian uprising, subsequently giving Noel and Daniel the basis on which to speculate about what was taking place in Poland. This resulted in a rich exchange of ideas about Moscow's strategy in resolving conflicts in its satellite countries:

\begin{tabular}{|c|c|}
\hline Teacher & Was Moscow justified in worrying about Solidarność? \\
\hline Noel & $\begin{array}{l}\text { Yes, because since they [the Polish] had the right to strike, they } \\
\text { could decide when to go back to work. }\end{array}$ \\
\hline Daniel & It's like having another [political] party now. \\
\hline Teacher & $\begin{array}{l}\text { This is interesting. It's like having another [political] party. That's } \\
\text { very close to how it [Solidarność] was working - a [political] party } \\
\text { against the communist government. True. }\end{array}$ \\
\hline Daniel & There is an opposition. \\
\hline Teacher & $\begin{array}{l}\text { That's right, and a big opposition it was - plus, there was in it the } \\
\text { Church, plus the other people, the intelligentsia. }\end{array}$ \\
\hline Daniel & They were in the majority. \\
\hline Teacher & Exactly. Clive. \\
\hline Clive & $\begin{array}{l}\text { Perhaps as had happened in Hungary, you can say that in the } \\
\text { same way that the Hungarians had rebelled and these [Soviets] } \\
\text { took everything back and everything came back to how they } \\
\text { wanted things to be, it could be that the Russians had in mind } \\
\text { to do the same as they had done in Hungary. }\end{array}$ \\
\hline Teacher & $\begin{array}{l}\text { So, you are saying that the Russians already had in mind to do } \\
\text { the same as they did in Hungary? }\end{array}$ \\
\hline Clive & They tried to. \\
\hline Teacher & So, it's like they gave them a chance. \\
\hline Clive & Yes. \\
\hline Noel & $\begin{array}{l}\text { Perhaps they [communists] were fearing that the government } \\
\text { would agree with them [the Polish people] and would itself try } \\
\text { to remove communism, as had happened in Czechoslovakia. }\end{array}$ \\
\hline Teacher & It could be. What you are saying is all good. \\
\hline Daniel & $\begin{array}{l}\text { About what Clive is saying, I don't think Hungary had as much } \\
\text { power as Poland because there was the Church with it and it was } \\
\text { all out; it has got much more power, all those people. }\end{array}$ \\
\hline & Yes, true. \\
\hline
\end{tabular}

On various occasions, students also showed a knowledge of substantive concepts gained from previous years. In the lesson 'The Iron Curtain', the USSR was seen by Gavin 'like an empire', and Franklin regarded what the Soviets were doing in postwar Germany as 'dictatorship from another country'. In the lesson 'The Berlin airlift', Franklin inferred that what Stalin was trying to do in Berlin 'was a kind of blockade', and according to Kyle an airlift was 'a type of convoy but instead on sea, by air'. From these examples, the concepts of 'empire', 'dictatorship', 'blockade' and 'convoy' the meaning of which students already knew - were equated with new knowledge and applied to new contexts, and thus helped enhance their understandings of the historical events. These examples also reveal students using their residue knowledge, which is long-lasting substantive knowledge required to recognize recurring features across topics, in a new context (Counsell, 2000).

Findings from this study show that students were able to encounter concepts in multiple contexts. This is an indication that knowledge of some substantive concepts gained from previous lessons, as well as from previous school years or from other 
sources of knowledge, perhaps even from outside school, facilitated students' sensemaking of new material related to the topic at hand.

\section{Discussing forms of historical knowledge in relation to each other}

There were instances when substantive and disciplinary knowledge came together in history topics (Hammond, 2016). Substantive knowledge consisted of: concepts; particulars; people (historical figures, groups of people); and historical context (location, time, wider context). Procedural knowledge consisted of: evidence; causation; consequences; change/continuity; significance; interpretation; and empathy. Table 3 shows that aspects of substantive knowledge were discussed mainly in relation to the second-order concept of evidence. This took place more frequently in writing tasks than in whole-class discussions. Political concepts and groups of people had a comparable number of references in both whole-class discussions and writing tasks. A representative example of a political concept developed in the context of evidence can be taken from the lesson 'The building of the Berlin Wall', in which students were encouraged to think in terms of the purpose of the British Pathé newsreel. Students' explanations showed awareness of the propaganda underlying the images: 'They are, like, telling people, "Look how fortunate you are that you are on our side"' (Gavin); 'Brainwashing ... They are proud they are living in the West' (Kyle).

Concerning groups of people mentioned in the context of evidence (for example, discussing the purpose, reliability and significance of moving images, and comparing and contrasting sources), when students were asked in writing tasks, 'Which historical details are mentioned in the documentary?' or 'What does the documentary tell us about life in Berlin?', students referred to people's actions in their answers, as these examples about the building of the Berlin Wall illustrate: 'People were confused by waking up and finding a wall dividing Berlin, which led to separation and [sic] families' (Gavin); 'The Soviets mistreated their people ... and shocked them with the building of the wall' (Franklin).

Causes and consequences developed mainly in relation to political concepts and groups of people. Causal reasoning was demonstrated most frequently in writing tasks. Teacher questions during classroom conversations encouraging causal reasoning in relation to groups of people featured most often in the Hungarian revolt lesson. Such questions included: 'Why did the people of Hungary take to the streets?'; 'Why do you think did [Hungarian] demonstrators go to the radio station?' Consequences related mostly to political concepts during whole-class discussions, and to groups of people in writing tasks.

Empathetic comments were most often made in relation to groups of people, and the majority of them were made verbally in class. Typically, students would comment about how people present in the moving images might have felt (for example, 'Perhaps he [a man hitting the Berlin Wall] was about to see his daughter') or how they themselves would have reacted if they had been present (for example, 'Imagine you're inside [the World Trade Center] and see it [plane] coming towards you').

Interpretation in writing tasks mainly concerned individual historical figures and groups of people. For example, interpretation was solicited about how Mikhail Gorbachev was seen in the eyes of the West, and in the eyes of the Russian people. By giving their opinion of Gorbachev, students' answers show how they interpreted Gorbachev in light of the documentary they had watched: 'In the eyes of the West, Gorbachev was seen as a hero, someone that works in favour of peace between the US and the USSR. They saw a leader with an open mind ...' (Gavin); 'A traitor for certain Russians; for others he was a saviour' (Franklin); 'Gorbachev was a man who did not 


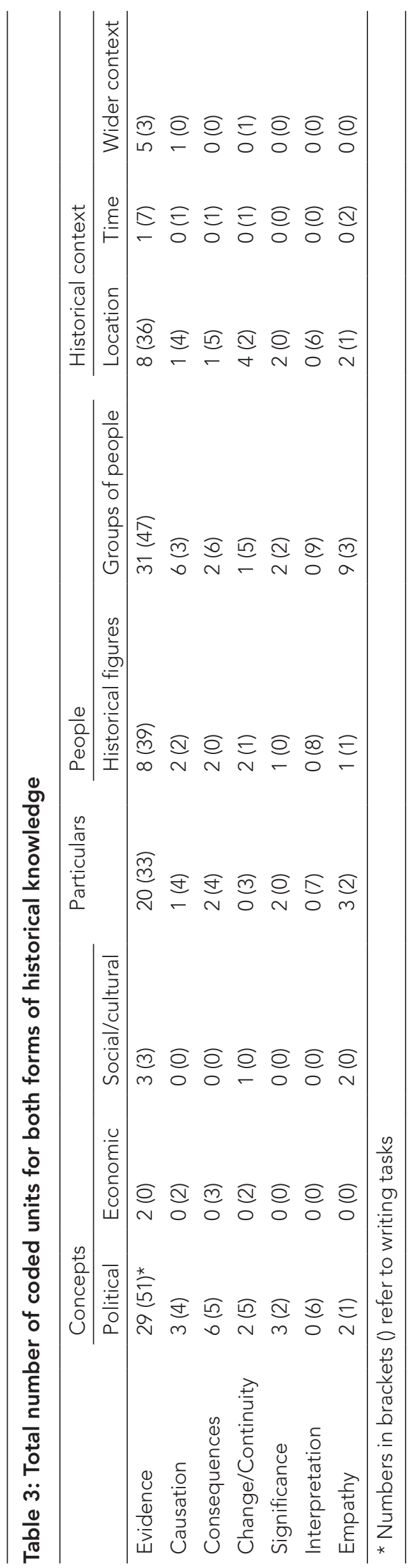


fear communism, because Gorbachev wanted to bring about great change in order to make his country better' (Kyle). These responses also returned references to groups of people, in this case to Russian people.

Historical contextual and procedural knowledge were mainly discussed in terms of evidence. The most referenced aspect of the historical context was location. It was very common for students to refer to the location of events when discussing or answering questions. One question in the writing task related to the lesson 'Solidarność' was: "'Moscow watched with growing alarm." Why was Solidarność an alarming development for the USSR?' The answer given by Adrian shows how students typically took into consideration the location of events when considering the historical context: 'It was an alarming development because it was happening in the biggest satellite of the Soviet Union, and by this development, Poland was like a nail in the Soviet's shoe'.

Further analysis showed that in analysing moving images, an accent was placed on substantive knowledge, indicated by the lack of reference to procedural knowledge in writing tasks and by units of verbal data coded only for substantive knowledge. Perhaps given that it may be 'natural' for students to follow what is going on in moving images by watching and listening, thinking about discussing second-order concepts that is, as historians do - might not come so easily.

It is suggested that an adequate amount of substantive knowledge helped students work with second-order concepts, and that a sound procedural knowledge, evidenced in discussions about, for instance, status, purpose and reliability, helped them make sense of the historical content presented in moving images.

\section{Connecting with the wider historical picture}

A number of comments showed a regard for the wider historical context. These were not directly related to what was shown in the moving images but took into consideration a wider, large-scale view spanning time and context. This view was referred to verbally in class on 58 separate occasions, and in four writing tasks (see Figure 1). Detailed analysis shows that, of these, 40 (70\%) were made by ten students and 18 (30\%) by me. Typical comments were: 'It's like in the West - they [people] had to learn English. And these [Polish] had to learn Russian' (Simon); and 'From the Russian, the communist, point of view did they [communists] agree with Gorbachev in bringing the [Berlin] Wall down?' (Noel).

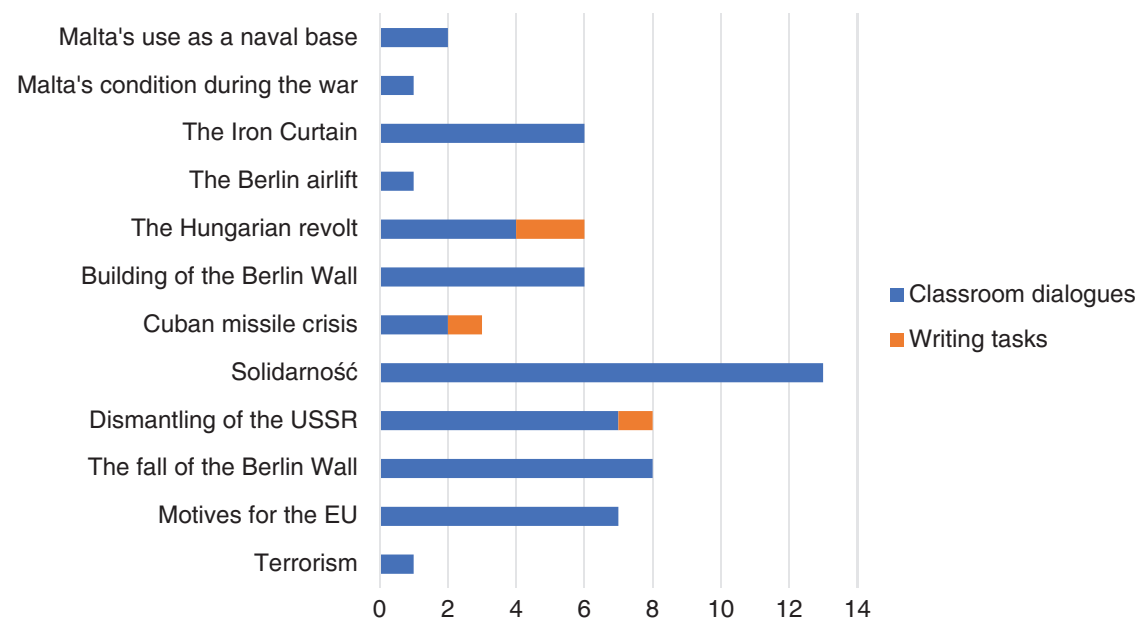

Figure 1: Frequency of students' references to the wider historical picture for each lesson 
Such comments were not made often, and not all students were capable of expanding their thoughts in this way frequently. This would seem to accord with Van Boxtel and Van Drie's (2012) observation that knowledge of long-term development is rarely verbalized. Although some students may do this on their own, as shown, the onus is on the teacher to help students achieve this understanding. Evidence points towards two practical approaches: first, teacher questions (for example, 'How is the footage seen related to the spread of Soviet influence in Eastern Europe?'); second, concept maps, in which students link concepts and ideas in relation to a main concept or theme (for example, the Cold War). Such approaches encourage students to think in terms of a topic-wide and century-wide historical picture.

\section{Constructing meaning using various language strategies}

Students were found to develop their historical understanding by: describing, explaining, speculating, inferring and asking questions (see Figure 2). Students were most often found to be describing and explaining, that is, they were found to identify and comment about elements in the moving image, as well as bringing their own knowledge to the discussions. Students also made inferences and speculations, and asked questions. Inferences were made when students formed an opinion or reached a conclusion based upon facts. By speculating, students were making comments without firm evidence. Students also asked questions when wanting to enquire about something. These strategies came into play more when discussing knowledge of a substantive nature, and they were most evident when discussing matters in class as a whole group, rather than individually in writing tasks.

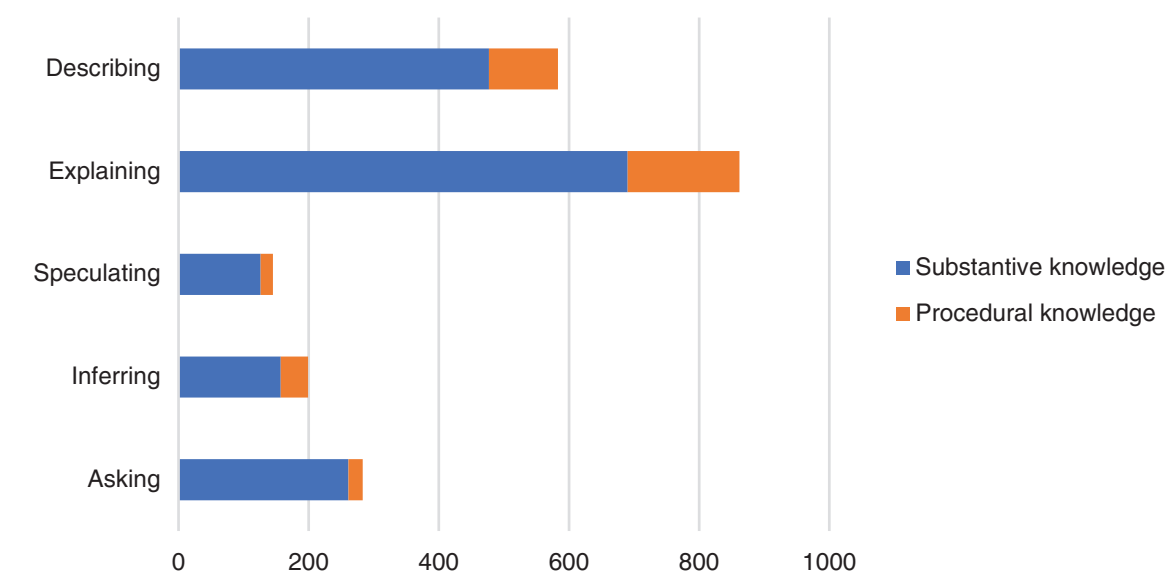

Figure 2: Frequency of strategies students used to construct historical knowledge

Especially regarding the concepts of 'communism' and 'democracy', which were regularly encountered in 'The Cold War' lessons, students described how Lech Wałęsa referred to communism as 'a monster'. Kyle explained the concept of democracy in the context of the fall of the Berlin Wall thus: 'It's as if each blow is ushering democracy. It was a ray of light for democracy.' Moreover, from Ronald Reagan's 'Tear down this Wall' speech, Simon and Daniel inferred that 'communism was weak' and that 'it was over by this time'. When considering whether people were expecting that the developments of 8 November 1989 could ever happen, typical speculative comments were: 'The Wall had stood for 28 years and, therefore, after all that time it would not fall' (Noel); 'I think otherwise. The communists had been dragging their feet, and they could suppose that one day it would fall' (Daniel). Questions were asked in relation to both substantive and procedural knowledge. 
These strategies reveal how knowledge co-construction, which is a key feature of a constructivist classroom (Deaney et al., 2009), may occur in the history classroom. Nichol (2009: 42) explains that constructivist teaching involves 'the teacher and the students working together to create understanding through an interactive, driving, focused pedagogy'. These findings also indicate that rather than passively consuming information, students were engaged with moving images in order to arrive at an understanding of events through a variety of styles of talk.

\section{Discussion}

Given the features they reveal, these findings offer a characterization of historical understanding when analysing broadcast media footage in a constructivist classroom. Thus, building on Newton (2012), I argue that in a constructivist context, historical understanding is about making multifarious connections and building personal understandings. As shown, understanding was supported when students saw and made connections not only between what they watched in the moving images and what they already knew (prior knowledge), but also between topics, between forms of historical knowledge, and with the broader historical context. Related to this was how students went about developing their historical understanding, which involved various language styles.

When students analysed coverage of historical events in real-time footage and listened to the voice-over narration or commentary, they seemed to attach the visual and auditory content to something they already knew, thereby opening up an idea for a point to be made. This was made in a think-aloud fashion, without teacher or peer prompting. The ability of the brain to make connections is explained by Greene (2012: 184):

The brain is an instrument for making connections. It operates as a dual processing system, in which every bit of information that comes in is at the same time compared to other information. The brain is constantly searching for similarities, differences and relationships between what it processes.

This finding also resonates with the multimedia learning principle (Mayer and Sims, 1994), in that students were using visual material alongside verbal narration to construct knowledge. It could be argued that such connections were being stimulated when watching moving images. From a pedagogical perspective, this highlights the attention that teachers should pay to selecting moving images for use in the classroom.

Knowledge that students gained in one topic and used to shape their knowledge of another was most often revealed in the use of substantive concepts. It has long been established in history education that students learn more each time they encounter substantive concepts in history lessons (Levstik and Barton, 2001). Given that the Maltese Year 11 history option syllabus (DLAP, 2012) deals with topics such as 'The World Wars', 'The Cold War' and 'European integration', concepts such as 'war', 'democracy' and 'communism' are bound to surface in multiple contexts. In this study, the concept of 'war' not only spread across different lessons, but also across different topics. Evidence shows that what students learned about 'war' was a combination of understandings. In relation to the Cold War, the main understanding that students developed from one lesson to another was that the West and East were locked in an ever-present feeling of 'fear of another war', which led each side not to get involved in a full-scale conflict. With the topic 'Malta during the Second World War', students could see the tangible 
side of the concept (because it involved physical conflict), whereas with 'The Cold War' topic, the concept assumed a more abstract dimension (due to the absence of physical conflict).

In discussing forms of historical knowledge in relation to each other, the pattern that emerged was that substantive knowledge was discussed more in terms of evidence than any other second-order concept. This is legitimate, given that one of the aims of the Maltese history option syllabus (DLAP, 2012) is for knowledge to be rooted in an understanding of the nature and use of historical evidence and, in terms of assessment, to see how far students master the evaluation and interpretation of evidence.

Another important finding concerned the concept of empathy, which seemed important for understanding human action. For example, students understood how British Pathé wartime newsreel footage helped shape the attitude of the Maltese towards the war effort, and they frequently placed themselves in the position of people living in Eastern European countries by commenting about what they would have done in their stead. This discussion relates to the literature in two ways: first, it shows that empathetic understanding affects the way students construct a historical context (De Leur et al., 2017; Pickles, 2010b); second, it shows how students operate at the higher levels of empathetic reasoning identified by Shemilt (1987). As not all students are capable of such reasoning, and being conscious of how important it is in history to understand human action in past times, teacher questions encouraging students to adopt an empathetic stance to particular situations are a necessary requirement for historical understanding. In this regard, it could be suggested that moving images, through their dynamic unfolding of events, and through being essentially about people, may lend themselves to encouraging empathetic comments and feelings.

It is worth noting that substantive knowledge featured highly when analysing moving images. Although on its own this is not enough for an appropriate history education (Haydn, 2011), this point supports Wineburg's (2007) argument about how 'unnatural' historical thinking is, even in the context of using moving images. Based on this, therefore, it would be profitable for moving images to be paused at appropriate stages to allow discussion of the substantive content from a disciplinary point of view.

Haydn et al. (2015) make the point that an attempt must be made to put events or topics in an overall historical context in order for students to develop a meaningful sense of the past. In this study, I got a glimpse of students' attempts at building a 'big picture' of the past from comments showing a regard for the broad historical context. Although this was attempted by some students, only Noel was found to be taking this broad view often, with such questions as, 'If Russia wanted to join [the EU] would they [EU countries] have accepted her?' It might seem that Noel's attention went off on a tangent, and that he was thinking of something else when he should have been attentive to the moving images. But placing events within the large-scale historical context necessitates that students establish patterns and links across different time periods and different historical events (Haydn, 2011; Riley, 1999).

As Van Boxtel and Van Drie (2012) contend, opportunities to develop overview knowledge may be limited, since students encounter particular persons, events and developments once or twice in history curricula. In this study, given the topics, it was possible to meet historical figures (such as John F. Kennedy and Mikhail Gorbachev) and concepts (such as democracy and communism) more than once. Arguably, this made it possible for students to link their 'bits and pieces of knowledge' to the wider historical context, and moving images may have served as a useful tool.

Student strategies for developing an understanding of historical events by means of moving images have been identified as describing, explaining, speculating, 
inferring and asking. Although this was not a study in discourse analysis, analysing verbal data was important because classroom talk is considered to be a potential influence on the development of students' knowledge and understanding (Mercer, 2008). Two reflections are important. First, students were most often found to be describing and explaining. In terms of classroom pedagogy, this highlights the need for teachers to stress observation skills and build on what students already know. I contend that these are two essential approaches for developing a platform of understanding. While observation is required to access, engage and reflect on any image (Perkins, 1994), helping students to connect with previous understandings is necessary for learning (Levstik and Barton, 2001). Second, findings showed that inferences were mainly made in the context of people. It is clear that students make judgements based on evidence from the moving images. That students are ready to speculate verbally in class rather than in writings would seem to indicate that a classroom environment that promotes dialogue enables them to co-construct knowledge (Pintrich and Schunk, 2002). However, it may also show that students might not be as confident in speculating when writing, that is, when working on their own. This would seem to indicate the importance of the teacher stressing that by speculating, inferring and asking questions students would, like historians, put the historical content under more rigorous scrutiny.

Underlying these features was the activation and deployment of prior historical knowledge. Use of prior knowledge involves transferring historical knowledge to new contexts, and it offers a platform for developing more detailed and contextualized understanding (Cooper and West, 2009). In this study, this was evidenced in the associations students made with the visual and auditory content of moving-image sources, in how they used substantive knowledge, particularly concepts, derived from previous topics, and in connecting with the broad historical picture in order to make sense of the newly encountered material. Research has linked prior knowledge with student engagement by way of questioning; it has been found that students ask more questions if they have greater prior knowledge (Logtenberg et al., 2011; Otero and Graesser, 2001). In developing an understanding of a historical concept, Haenen et al. (2003) factor in students' existing knowledge. For them, the first step towards understanding a concept involves the teacher activating students' prior knowledge so that the concept is brought within the 'zone of proximal development' (Vygotsky, 1978). In this way, collaboratively and through talk, students explore the meaning and connections between concepts. Besides questioning, concept maps and wholeclass discussions are found to activate prior historical knowledge (Haenen et al., 2003; Van Drie and Van Boxtel, 2003). As was the case in the present study, students' prior knowledge about certain topics may be fragmentary or limited, and students may even hold an idée fixe; therefore, new knowledge encountered in the classroom will challenge their previous understandings. This should be seen as a positive learning outcome; as Levstik and Barton (2001) remark, the idea of teachers and students building on prior knowledge is to produce rather than reproduce knowledge.

What emanates from this scenario is that key to developing historical understanding when using moving images is the centrality of knowledge co-construction in wholeclass dialogues. Knowledge construction is a feature of constructivist teaching, and it includes such approaches as using previous knowledge and experiences as the starting point for new learning (Harris and Alexander, 1998) and encouraging talk that welcomes and explores various viewpoints (Van Drie and Van Boxtel, 2011). Learning takes on a constructivist stance when students are viewed as active learners coming to the classroom with their own ideas and, with the appropriate teacher scaffolding, are able to construct knowledge rather than merely receive it (Driver and Oldham, 1986). 
This study has shown that a history classroom using moving-image sources provides a context for this pedagogy with the aim of advancing students' historical understanding.

\section{Conclusions and recommendations}

Understanding has been seen in this study as both a knowledge-building and a meaningmaking act that helps students understand history in terms of both a body of content and disciplinary knowledge (Haydn, 2011). This paper has argued for the importance of making connections as a necessary requirement for historical understanding, and it has discussed ways in which students give form to understanding. The outcomes of the study highlight the importance of supporting students' prior knowledge. Based on the evidence discussed, some recommendations for practice and for further research can be proposed.

First, it is known that when visual and auditory information are presented together, brain activity during learning intensifies (Beauchamp et al., 2004). Present findings have shown that students made various connections involving prior knowledge. Even though this did not occur all the time that moving images were used, nevertheless it shows the tendency of the brain to make connections when reasoning. Therefore, an interesting line of research would be to understand students' reasoning while analysing moving images, such as those used in this study, from an educational neuroscience perspective. In this way, in line with research by De Jong et al. (1998) in science and mathematics, any implications concerning memory retention, recall, higher-order thinking and understanding for history education could be suggested.

Second, in researching the substantive-procedural connection, prevailing research is investigating how knowledge of one form helps address knowledge of another (Fordham, 2016). This issue has been explored in terms of substantive concepts (Fordham, 2016; Palek, 2015). As important as substantive concepts are to a history education, this exciting new line of investigation must take on board all areas of substantive knowledge, including people and the wider historical context, to fully understand the relation between the two forms of historical knowledge. This view prompts me to endorse a recently developed taxonomy of substantive knowledge covering a range of areas such as narratives, human stories, a sense of period and substantive concepts (Counsell, 2017), which is currently being researched.

Finally, given the importance attached to developing a big-picture understanding of history (Haydn, 2011), it would be useful for teachers to encourage students to think beyond the visual and auditory content of moving images. Indeed, by including questions that build on prior knowledge and help place events in a broad historical framework, teachers would address important aspects of historical understanding (Lee, 2005; Levstik and Barton, 2001). Done consistently throughout lessons, students would come to see this as an important feature of the analysis of moving images.

Given the design and participants of the study, which mean that generalizations are beyond its scope, the aspects covered here do not lay claim to a comprehensive characterization of historical understanding, but the evidence discussed, along with the recommendations made, offer a platform for further research into aspects of what historical understanding is about and how it may be supported.

\section{Acknowledgements}

I thank Professor lan Davies (University of York) and Professor Yosanne Vella (University of Malta) for their feedback on earlier versions of this paper. 


\section{Notes on the contributor}

Alexander Cutajar is Head of the Department of History at St Ignatius College, Malta, and a visiting lecturer at the University of Malta. His PhD (University of York) investigated the use of moving images in the history classroom. His publications include a history book, chapters in history textbooks and papers about various aspects of history education. He is treasurer of the History Teachers' Association (Malta) and trainer for EuroClio - the European Association of History Educators.

\section{References}

Alexander, R. (2008) Towards Dialogic Teaching: Rethinking classroom talk. 4th ed. York: Dialogos.

Ashby, R., Lee, P.J. and Shemilt, D. (2005) 'Putting principles into practice: Teaching and planning'. In National Research Council (US), Brandsford, D. and Donovan, M.S. (eds), How Students Learn: History, mathematics and science in the classroom. Committee on How People Learn, Targeted Report for Teachers. Washington, DC: The National Academies Press, 79-178.

Banham, D. and Hall, R. (2003) 'JFK: The medium, the message, the myth'. Teaching History, 113, 6-12.

Beauchamp, M.S., Lee, K.E., Argall, B.D. and Martin, A. (2004) 'Integration of auditory and visual information about subjects in superior temporal sulcus'. Neuron, 41 (5), 809-23. Online. https://doi.org/10.1016/S0896-6273(04)00070-4

Card, J. (2011) 'Seeing the point: Using visual sources to understand the arguments for women's suffrage'. Teaching History, 143, 15-19.

Chi, M.T.H. (1997) 'Quantifying qualitative analyses of verbal data: A practical guide'. The Journal of the Learning Sciences, 6 (3), 271-315. Online. https://doi.org/10.1207/s15327809jls0603_1

Cooper, H. and West, L. (2009) 'Year 5/6 and Year 7 historians visit Brougham Castle'. In Cooper, H. and Chapman, A. (eds) Constructing History 11-19. London: Sage, 9-32.

Counsell, C. (2000) 'Historical knowledge and historical skills: A distracting dichotomy'. In Arthur, J. and Phillips, R. (eds) Issues in History Teaching. London: Routledge, 54-71.

Counsell, C. (2011) 'Disciplinary knowledge for all, the secondary history curriculum and history teachers' achievement'. The Curriculum Journal, 22 (2), 201-25. Online. https://doi.org/10.1080/0 9585176.2011 .574951

Counsell, C. (2017) 'The fertility of substantive knowledge: In search of its hidden, generative power'. In Davies, I. (ed.) Debates in History Teaching. 2nd ed. London: Routledge, 80-99.

Cutajar, A. (2018) 'Students' engagement with historical film's moving images in a Maltese secondary history classroom'. History Education Research Journal, 15 (2), 355-68. Online. https://doi.org/10.18546/HERJ.15.2.14

Deaney, R., Chapman, A. and Hennessy, S. (2009) 'A case-study of one teacher's use of an interactive whiteboard system to support knowledge construction in the history classroom'. The Curriculum Journal, 20 (4), 365-87. Online. https://doi.org/10.1080/09585170903424898

Delamont, S. (1990) 'A woman's place in education: Myths, monsters and misapprehensions'. Online. http://richardmillwood.net/bera/sites/default/files/Delamont\%20\%20presidential\%20 address\%201983.pdf (accessed 12 July 2019).

De Jong, T., Ainsworth, S., Dobson, M., Van der Hulst, A., Levonen, J., Reimann, P., Sime, J.A., Van Someren, M., Spada, H. and Swaak, J. (1998) 'Acquiring knowledge in science and mathematics: The use of multiple representations in technology based learning environments'. In Van Someren, M., Reimann, P., Boshuizen, H. and De Jong, T. (eds) Learning with Multiple Representations. Oxford: Elsevier Science, 9-41.

De Leur, T., Van Boxtel, C. and Wilschut, A. (2017) '"I saw angry people and broken statues": Historical empathy in secondary history education'. British Journal of Educational Studies, 65 (3), 331-52. Online. https://doi.org/10.1080/00071005.2017.1291902

DLAP (Directorate for Learning and Assessment Programmes) (2012) History (Option). Government of Malta. Online. https://curriculum.gov.mt/en/Curriculum/Year-9-to-11/Documents/curric_f3_f5/ syllabus_history_opt_f3_f4_f5_2014.pdf (accessed 12 July 2019).

Donnelly, D. (2013) 'Teaching history using feature films: Practitioner acuity and cognitive neuroscientific validation'. International Journal of Historical Learning, Teaching and Research [now History Education Research Journal], 12 (2), 16-27. Online. https://doi.org/10.18546/ herj.12.1.03

Donnelly, D. (2016) 'Filmic pedagogies in the teaching of history: Research on and recommendations for using video in the classroom'. International Journal of Historical Learning, 
Teaching and Research [now History Education Research Journal], 14 (1), 113-23.

Online. https://doi.org/10.18546/HERJ.14.1.09

Driver, R. and Oldham, V. (1986) 'A constructivist approach to curriculum development in science'. Studies in Science Education, 13 (1), 105-22. Online. https://doi.org/10.1080/03057268608559933

Fordham, M. (2015) 'Substantive knowledge and pupil progression in history'. In Cassar, G. and Vella, Y. (eds) History Teaching and Research: Bridging the theory/practice divide. Vol. 3. Malta: Faculty of Education, University of Malta and History Teachers' Association (Malta), 77-88.

Fordham, M. (2016) 'Knowledge and language: Being historical with substantive concepts'. In Counsell, C., Burn, K. and Chapman, A. (eds) MasterClass in History Education: Transforming teaching and learning. London: Bloomsbury Academic, 43-57.

Greene, R. (2012) Mastery. London: Profile Books.

Haenen, J., Schrijnemakers, H. and Stufkens, J. (2003) 'Transforming Year 7's understanding of the concept of imperialism: A case study on the Roman Empire'. Teaching History, 112, 28-34.

Hammond, K. (2014) 'The knowledge that "flavours" a claim: Towards building and assessing historical knowledge on three scales'. Teaching History, 157, 18-24.

Hammond, K. (2016) 'Exploring the relationship between substantive and disciplinary knowledge'. In Counsell, C., Burn, K. and Chapman, A. (eds) MasterClass in History Education: Transforming teaching and learning. London: Bloomsbury Academic, 167-72.

Harris, K.R. and Alexander, P.A. (1998) 'Integrated constructivist education: Challenge and reality'. Educational Psychology Review, 10 (2), 115-27. Online. https://doi.org/10.1023/A:1022169018926

Haydn, T. (2011) 'Secondary history: Current themes'. In Davies, I. (ed.) Debates in History Teaching. London: Routledge, 30-45.

Haydn, T., Stephen, A., Arthur, J. and Hunt, M. (2015) Learning to Teach History in the Secondary School. 4th ed. London: Routledge.

Husbands, C. (1996) What is History Teaching? Language, ideas and meaning in learning about the past. Buckingham: Open University Press.

Konnikova, M. (2013) Mastermind: How to think like Sherlock Holmes. New York: Penguin.

Lang, S. (2002) 'Mushrooms and snake-oil: Using film at AS/A level'. Teaching History, 108, 44-8. Online. http://www.jstor.org/stable/43259897 (accessed 27 August 2020).

Lee, P. (2005) 'Putting principles into practice'. In National Research Council (US), Brandsford, D. and Donovan, M.S. (eds) How Students Learn: History, mathematics and science in the classroom. Committee on How People Learn, Targeted Report for Teachers. Washington, DC: The National Academies Press, 31-74.

Lee, P. and Ashby, R. (2000) 'Progression in historical understanding among students ages 7-14'. In Stears, P.N., Seixas, P. and Wineburg, S. (eds) Knowing, Teaching and Learning History: National and international perspectives. New York: New York University Press, 199-222.

Lévesque, S. (2008) Thinking Historically: Educating students for the twenty-first century. Toronto: University of Toronto Press.

Levstik, L. and Barton, K. (2001) Doing History: Investigating with children in elementary and middle schools. 2nd ed. Mahwah, NJ: Lawrence Erlbaum Associates.

Logtenberg, A., Van Boxtel, C. and Van Hout-Wolters, B. (2011) 'Stimulating situational interest and student questioning through three types of historical introductory texts'. European Journal of Psychology of Education, 26 (2), 179-98. Online. https://doi.org/10.1007/s10212-010-0041-6

Marcus, A.S. (2005) '"It is as it was": Feature film in the history classroom'. The Social Studies, 96 (2), 61-7. Online. https://doi.org/10.3200/TSSS.96.2.61-67

Marcus, A.S., Paxton, R.J. and Meyerson, P. (2006) "'The reality of it all": History students read the movies'. Theory and Research in Social Education, 34 (4), 516-52. Online. https://doi.org/10.1080 /00933104.2006.10473320

Marcus, A.S. and Stoddard, J.D. (2007) 'Tinsel Town as teacher: Hollywood film in the high school classroom'. The History Teacher, 40 (3), 303-30. Online. www.jstor.org/stable/30036826 (accessed 27 August 2020).

Marcus, A.S. and Stoddard, J.D. (2009) 'The inconvenient truth about teaching history with documentary film: Strategies for presenting multiple perspectives and teaching controversial issues'. The Social Studies, 100 (6), 279-84. Online. https://doi.org/10.1080/00377990903283957

Mayer, R.E. and Sims, V.K. (1994) 'For whom is a picture worth a thousand words? Extensions of a dual-coding theory of multimedia learning'. Journal of Educational Psychology, 86 (3), 389-401. Online. https://doi.org/10.1037/0022-0663.86.3.389

Mercer, N. (2008) 'Talk and the development of reasoning and understanding'. Human Development, 51 (1), 90-100. Online. https://doi.org/10.1159/000113158 
Metzger, S.A. and Suh, Y. (2008) 'Significant or safe? Two cases of instructional uses of history feature films'. Theory and Research in Social Education, 36 (1), 88-109. Online. https://doi.org/10.1080/00933104.2008.10473361

Mitchell Cates, W. (1990) 'Helping students learn to think critically: Detecting bias and analyzing bias in films'. The Social Studies, 81 (1), 15-18. Online. https://doi.org/10.1080/00377996.1 990.9957486

Morgan, P. (2010) 'How can we deepen and broaden post-16 students' historical engagement with the Holocaust? Developing a rationale and methods for using film'. Teaching History, 141, 27-32.

Newton, D.P. (2012) Teaching for Understanding: What it is and how to do it. 2nd ed. London: Routledge.

Nichol, J. (2009) 'Bringing the history curriculum to life for Year 8/9'. In Cooper, H. and Chapman, A. (eds) Constructing History 11-19. London: Sage, 33-62.

Otero, J. and Graesser, C.C. (2001) 'PREG: Elements of a model of question asking'. Cognition and Instruction, 19 (2), 143-75. Online. https://doi.org/10.1207/S1532690XCl1902_01

Palek, D. (2015) '"What exactly is parliament?" Finding the place of substantive knowledge in history'. Teaching History, 158, 18-25.

Perkins, D.N. (1994) The Intelligent Eye: Learning to think by looking at art. Santa Monica, CA: Getty Publications.

Pickles, E. (2010a) 'Valid assessment of students' use of historical sources'. International Journal of Historical Learning, Teaching and Research [now History Education Research Journal], 9 (2), 75-84.

Pickles, E. (2010b) 'How can students' use of historical evidence be enhanced? A research study of the role of knowledge in Year 8 to Year 13 students' interpretations of historical sources'. Teaching History, 139, 41-51.

Pintrich, P.R. and Schunk, D.H. (2002) Motivation in Education: Theory, research, and applications. 2nd ed. Englewood Cliffs, NJ: Merill Prentice Hall.

Riley, C. (1999) 'Evidential understanding, period knowledge and the development of literacy: A practical approach to "layers of inference" for Key Stage 3'. Teaching History, 97, 6-12.

Seixas, P. (1994) 'Confronting the moral frames of popular film: Young people respond to historical revisionism'. American Journal of Education, 102 (3), 261-85. Online. www.jstor.org/ stable/1085738 (accessed 27 August 2020).

Seixas, P. (1996) 'Conceptualizing the growth of historical understanding'. In Olson, D.R. and Torrance, N. (eds) The Handbook of Education and Human Development. Oxford: Blackwell, 765-83.

Shemilt, D. (1987) 'Adolescent ideas about evidence and methodology in history'. In Portal, C. (ed.) The History Curriculum for Teachers. London: The Falmer Press, 39-61.

Shemilt, D. (2009) 'Drinking an ocean and pissing a cupful'. In Symcox, L. and Wilschut, A. (eds) National History Standards: The problem of the canon and the future of teaching history. Charlotte, NC: Information Age Publishing, 141-210.

Van Boxtel, C. and Van Drie, J. (2012) '“That's in the time of the Romans!' Knowledge and strategies students use to contextualize historical images and documents'. Cognition and Instruction, 30 (2), 113-45. Online. https://doi.org/10.1080/07370008.2012.661813

Van Boxtel, C. and Van Drie, J. (2013) 'Historical reasoning in the classroom: What does it look like and how can we enhance it?' Teaching History, 150, 44-52.

Vanderlinde, R. and Van Braak, J. (2010) 'The gap between educational research and practice: Views of teachers, school leaders, intermediaries and researchers'. British Educational Research Journal, 36 (2), 299-316. Online. https://doi.org/10.1080/01411920902919257

Van Drie, J. and Van Boxtel, C. (2003) 'Developing conceptual understanding through talk and mapping'. Teaching History, 110, 27-31.

Van Drie, J. and Van Boxtel, C. (2010) 'Chatting about the sixties: Using on-line chat discussion to improve historical reasoning in essay-writing'. Teaching History, 140, 38-46. Online. https://hdl.handle.net/11245/1.345086 (accessed 27 August 2020).

Van Drie, J. and Van Boxtel, C. (2011) '“In essence I'm only reflecting": Teacher strategies for fostering historical reasoning in whole-class discussions'. International Journal of Historical Teaching, Learning and Research [now History Education Research Journal], 10 (1), 55-66. Online. https://doi.org/10.18546/HERJ.10.1.05

VanSledright, B.A. (2014) Assessing Historical Thinking and Understanding: Innovative designs for new standards. New York: Routledge.

Vygotsky, L.S. (1978) Mind in Society: The development of higher psychological processes. Cambridge, MA: Harvard University Press. 
White, R. and Gunstone, R. (1992) Probing Understanding. London: The Falmer Press.

Wilson, S., Floden, R. and Ferrini-Mundy, J. (2001) Teacher Preparation Research: Current knowledge, gaps, and recommendations. Washington, DC: Center for the Study of Teaching and Policy.

Wineburg, S. (2007) 'Unnatural and essential: The nature of historical thinking'. Teaching History, $129,6-11$

Woelders, A. (2007) '“It makes you think more when you watch things": Scaffolding for historical inquiry using film in the middle school classroom'. The Social Studies, 98 (4), 145-52.

Online. https://doi.org/10.3200/TSSS.98.4.145-152 